\title{
Catecholamines Are Mitogenic in 3T3 and Bovine Aortic Endothelial Cells
}

\author{
Peter Sherline and Renato Mascardo \\ Department of Medicine, University of Connecticut School of \\ Medicine, Farmington, Connecticut 06032
}

A

bstract. We have found that catecholamines stimulate DNA synthesis and centrosomal separation in $3 \mathrm{~T} 3$ and bovine aortic endothelial cells cultured in the absence of serum or added growth factors. The mitogenic effect is mediated by an $\alpha_{1}$-adrenergic receptor, as it is inhibited by phentolamine and prazosin but not by propranolol or yohimbine. The physiological and pathological consequences of this effect remain to be determined.

\section{Introduction}

We recently found that stimulation of DNA synthesis by epidermal growth factor was associated with rapid centrosomal separation in a variety of cell types (1-3). In the course of investigating the effects of other growth factors on centrosomal separation we found that epinephrine and norepinephrine also increased centrosomal separation, which suggests that catecholamines might be mitogenic as well. The present report describes studies in mouse 3T3 cells and bovine aortic endothelial cells, which demonstrate that alpha adrenergic agonists stimulate DNA synthesis in the absence of serum or added growth factors.

\section{Methods}

Bovine aortic endothelial (BAE) ${ }^{1}$ cells (a kind gift of $\mathrm{K}$. Butterfield in the laboratory of Dr. J. Folkman) were cultured in Dulbecco's modified Eagle's medium (DMEM) with 10\% fetal calf serum (Sterile Systems Inc., Logan, UT) and were used between the 6th and 12th passage after isolation. BALB/c mouse 3T3 cells (American Type Culture Collection) were cultured in DMEM containing 10\% calf serum. Cells were plated on 12-mm diam coverslips in 24-well multiwells (Costar, Data Packaging, Cambridge, MA) at an initial density of $150,000 / \mathrm{ml} .24 \mathrm{~h}$ after plating, the medium was replaced with DMEM lacking serum and the cells were cultured for another $30 \mathrm{~h}$ before the addition of the test agent. After an additional $16 \mathrm{~h},\left[{ }^{3} \mathrm{H}\right]$ thymidine was added to each well $(1 \mu \mathrm{Ci} / \mathrm{ml} ; 6.7$

Received for publication 1 February 1984.

1. Abbreviations used in this paper: BAE, bovine aortic endothelial; DMEM, Dulbecco's modified Eagle's medium; EGF, epidermal growth factor.

J. Clin. Invest.

(C) The American Society for Clinical Investigation, Inc. 0021-9738/84/08/0483/05 \$1.00

Volume 74, August 1984, 483-487
$\mathrm{Ci} / \mathrm{mmol}$ ) and the cells were fixed and processed for autoradiography (4) $2 \mathrm{~h}$ thereafter. For the time-course study (Fig. 2) the $\left[{ }^{3} \mathrm{H}\right]$ thymidine was added along with epinephrine, $30 \mathrm{~h}$ after serum deprivation and cells were fixed at the indicated times so that, in this case, a cumulative labeling index was determined.

Centrosomal separation was studied in parallel coverslips by using indirect immunofluorescence as previously described (2). With the exception of the experiment described in Fig. 2 test agents were added 46 $h$ after serum deprivation and cells were fixed and processed for immunofluorescence $2 \mathrm{~h}$ later. The rat monoclonal anti-tubulin antibody used to stain microtubules (Fig. 1) was a gift of Dr. J. Kilmartin. All catecholamines and blockers were from Sigma Chemical Co. (St. Louis, MO) with the exception of phentolamine (Ciba-Geigy Corp., Summit, $\mathrm{NJ}$ ) and prazosin (Pfizer, Inc., New York). Epidermal growth factor (EGF) was from Collaborative Research, Inc. (Waltham, MA) and W-5 and W-7 were from Caabco Inc. (Houston, TX). Trifluoperazine was a gift of C. Kaiser (Smith Kline Corp., Sunnyvale, CA).

\section{Results and Discussion}

The time course of the epinephrine-induced centrosomal separation and entrance into $S$ phase is shown in Fig. 2. Centrosomal separation precedes the increase in labeling index by 3-6 $\mathrm{h}$ in both $3 T 3$ and BAE cells. Note that the maximal effect of epinephrine on both parameters is comparable to that of an optimal concentration of EGF $(20 \mathrm{ng} / \mathrm{ml})$. Unstimulated cells showed no increase in either centrosomal separation or labeling index during the course of the experiment. The maximal effect of epinephrine on labeling index is reached at $10^{-6} \mathrm{M}$ (Fig. 3). A similar concentration dependence was found for centrosomal separation (not shown). To demonstrate that cells stimulated by epinephrine were capable of progressing through the remainder of the cell cycle and replicating we studied the increase in cell number of cells grown in the presence or absence of epinephrine for $45 \mathrm{~h}$ (Table I). As is evident, epinephrine alone, in the absence of calf serum or other added growth factors, caused a significant increase in cell number over unstimulated controls at both 24 and $45 \mathrm{~h}$. The effect was comparable to that of an optimal concentration of EGF $(20 \mathrm{ng} / \mathrm{ml})$ in EC cells but was somewhat less in $3 \mathrm{~T} 3$ cells. $10 \%$ fetal calf serum was substantially more effective than either epinephrine or EGF as might be expected.

Fig. 4 shows that norepinephrine and phenylephrine were as effective in stimulating DNA synthesis as epinephrine in both cell types whereas isoproterenol had little effect. These results 

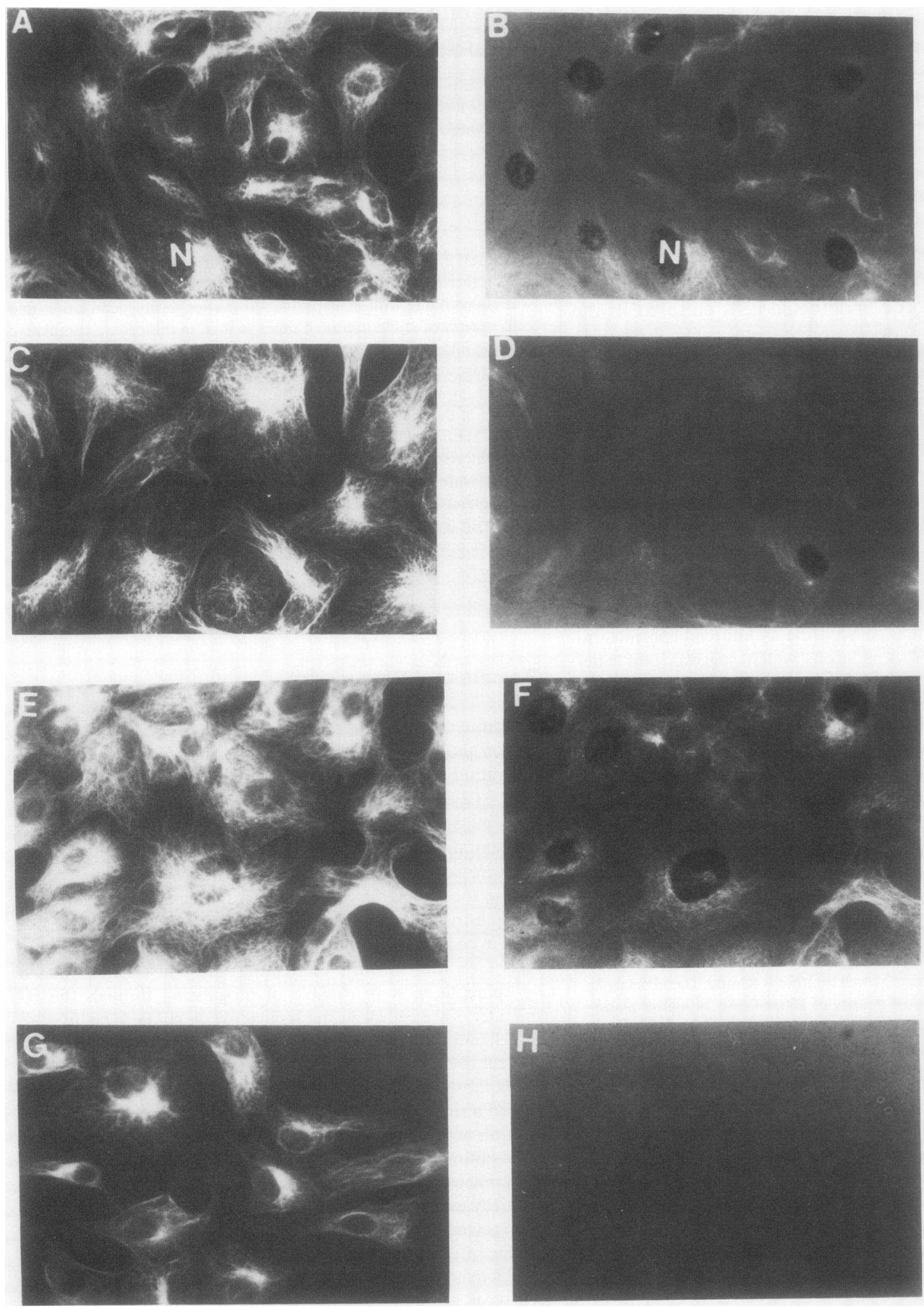

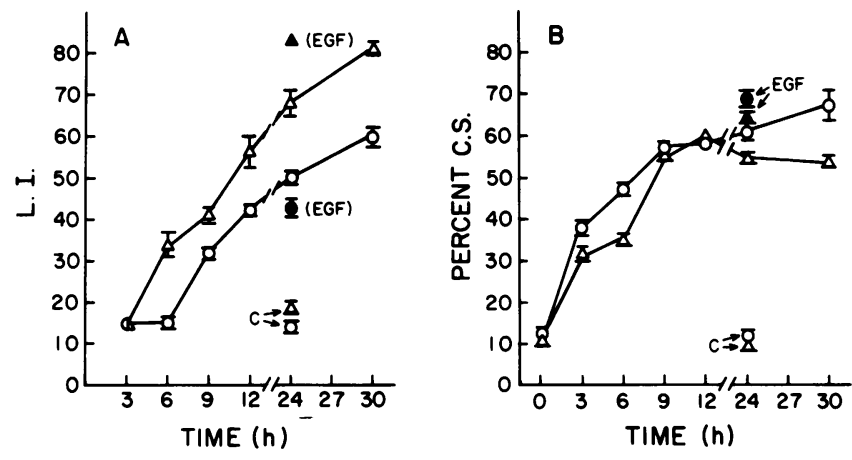

Figure 2. Time course of epinephrine-stimulated DNA synthesis and centrosomal separation. BAE or 3T3 cells were grown on coverslips for $24 \mathrm{~h}$ before serum deprivation for an additional $30 \mathrm{~h}$. Epinephrine $\left(10^{-5} \mathrm{M}\right)$ was then added along with $\left[{ }^{3} \mathrm{H}\right]$ thymidine $(1 \mu \mathrm{Ci} / \mathrm{ml})$ and cells were fixed and processed for autoradiography $(A)$ or immunofluorescence $(B)$ at the indicated times. L.I., labeling index; C.S., centrosomal separation; $C$, control cells to which no additions were made. $O$, values in BAE cells; $\triangle$, values in $3 T 3$ cells. The response to EGF $(20 \mathrm{ng} / \mathrm{ml})$ is indicated by filled circles (BAE) or triangles (3T3). Values represent the mean \pm SEM of duplicate coverslips. 200 cells per coverslip were counted.

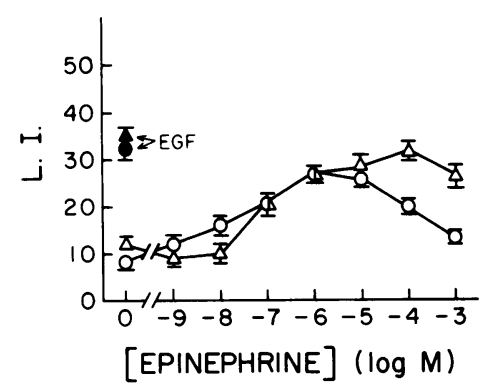

Figure 3. Concentration-dependence of epinephrinestimulated DNA synthesis. Cells were plated for $24 \mathrm{~h}$, serum-deprived for $30 \mathrm{~h}$, and stimulated with epinephrine for $18 \mathrm{~h}$ before fixation and processing for autoradiography. $\left[{ }^{3} \mathrm{H}\right]$ Thymidine $(1 \mu \mathrm{Ci} / \mathrm{ml})$ was added $2 \mathrm{~h}$ before fixation. Denotation of symbols as in Fig. 1.

suggested that mitogenesis was mediated by alpha adrenergic stimulation. This was substantiated by demonstrating that phentolamine but not propranolol blocked the mitogenic effect of epinephrine (Fig. 5). Phentolamine had no effect on EGFinduced mitogenesis (not shown). The $\alpha_{2}$-specific agonist clonidine had no effect by itself and inhibited the DNA synthetic response to epinephrine. Prazosin, an $\alpha_{1}$ specific blocker, inhibited the epinephrine effect whereas yohimbine, an $\alpha_{2}$ specific
Table I. Effect of Epinephrine and EGF on Cell Proliferation

\begin{tabular}{llll}
\hline Time after addition: & $0 \mathrm{~h}$ & $24 \mathrm{~h}$ & $45 \mathrm{~h}$ \\
\hline EC & & & \\
$\quad$ DMEM only & $13,572 \pm 3,100$ & $15,138 \pm 3,100$ & $14,250 \pm 2,300$ \\
$\quad$ + Epinephrine & $10,962 \pm 500$ & $24,534 \pm 250$ & $25,317 \pm 580$ \\
$\quad$ + EGF & $15,138 \pm 2,600$ & $24,550 \pm 3,700$ & $29,388 \pm 2,210$ \\
$\quad$ +10\% FCS & $16,710 \pm 1,050$ & $33,408 \pm 4,100$ & $61,074 \pm 5,200$ \\
3T3 & & & \\
DMEM only & $15,660 \pm 350$ & $13,572 \pm 700$ & $12,684 \pm 1,980$ \\
$\quad$ + Epinephrine & $13,920 \pm 2,446$ & $18,792 \pm 700$ & $21,767 \pm 730$ \\
$\quad$ + EGF & $16,182 \pm 1,800$ & $25,056 \pm 1,800$ & $34,869 \pm 360$ \\
$\quad$ + 10\% FCS & $17,750 \pm 2,900$ & $35,496 \pm 6,200$ & $80,910 \pm 8,800$
\end{tabular}

Bovine aortic endothelial cells (EC) or 3T3 cells were plated in wells of a 24 well multiwell and allowed to attach for $24 \mathrm{~h}$ in the presence of $10 \%$ fetal calf serum (FCS). The medium was then replaced with DMEM lacking serum and the cells were cultured for another $24 \mathrm{~h}$, after which time the number of cells in each well was determined by counting the cells in four randomly selected fields under an inverted microscope and multiplying by the appropriate factor (the ratio of the area of the well to the area of the field). Epinephrine $\left(10^{-5} \mathrm{M}\right)$, epidermal growth factor (EGF, $20 \mathrm{ng} / \mathrm{ml}$ ) or FCS was added to duplicate wells and the cultures were continued for an additional $45 \mathrm{~h}$. Cell number was determined at 0,24 , and $45 \mathrm{~h}$. Values represent the mean $\pm \mathrm{SD}$ of cell number in replicate wells.

blocker, did not inhibit the epinephrine effect and, surprisingly, was itself a stimulator of DNA synthesis in both cell types (Table II). Thus, $\alpha_{1}$-receptor activation mediates the stimulation of DNA synthesis in these cells by catecholamines. In contrast, the effects of clonidine and yohimbine suggest an antimitogenic effect of $\alpha_{2}$ receptor activation. It is clear that, in these two cell types, the predominant effect of catecholamines is to stimulate mitogenesis and thus we can conclude that the $\alpha_{1}$-effect is dominant. Nevertheless, the possibility exists that in other cell types or under different conditions the $\alpha_{2}$-effect might become dominant and so result in inhibition of mitogenesis by catecholamines. The observation that yohimbine stimulates DNA synthesis in serum-free cultures suggests the intriguing possibility that an endogenous $\alpha_{2}$-specific agonist is secreted by the cells and acts as an auto-inhibitor of cell growth.

Fig. 6 shows that two structurally dissimilar calmodulin antagonists (trifluoperazine and $W-7$ ) inhibit entrance into $S$ phase induced by epinephrine. W-5, the dechlorinated analogue of $\mathrm{W}-7$, which is $1 / 5$ to $1 / 10$ as potent a calmodulin inhibitor in vitro $(5,6)$, has only a minimal effect. Parallel studies of centrosomal separation were done for the experiments presented in Figs. 2-6 with qualitatively similar results (not shown).
Figure 1. Immunofluorescence and light microscopy of 3T3 and endothelial cells. Mouse 3T3 and bovine aortic endothelial cells were grown on coverslips for $24 \mathrm{~h}$ in complete medium, serum-deprived for $30 \mathrm{~h}$, and then exposed to epinephrine $\left(10^{-5} \mathrm{M}\right)$ in the continued absence of serum for $18 \mathrm{~h}$ before fixation and processing for combined immunofluorescence-autoradiography. For immunofluorescence, cells were stained with a monoclonal rat anti-tubulin antibody. $\left[{ }^{3} \mathrm{H}\right]$ thymidine $(1 \mu \mathrm{Ci} / \mathrm{ml})$ was added $2 \mathrm{~h}$ before fixation. A given group of cells was observed microscopically through a fluorescein-specific filter $(A, C, E, G)$ and with bright field illumination $(B, D, F$, $H)$. In 3T3 cells $(A-D)$, eight labeled nuclei $(B)$ out of $20(A)$ are seen in a field of cells that had been exposed to epinephrine. Only one nucleus is labeled $(D)$ out of $12(C)$ in a field of unstimulated cells. In endothelial cells $(E-H), 6(F)$ of $17(E)$ cells exposed to epinephrine are labeled. A field of control cells $(G)$ showed no nuclear labeling $(H) . N$, nucleus. $\times 800$. 


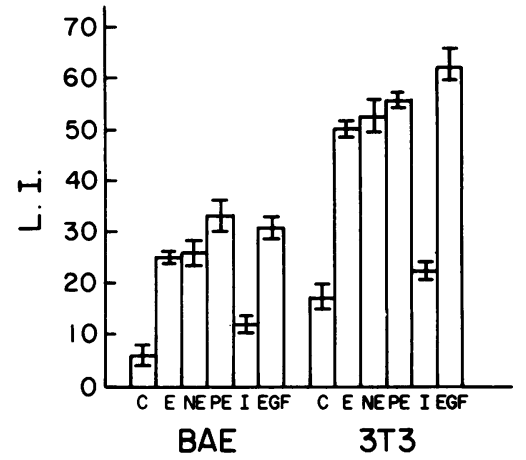

Figure 4. Effect of catecholamines on DNA synthesis in BAE and $3 T 3$ cells. $C$, control (no addition); E, epinephrine $\left(10^{-5} \mathrm{M}\right)$; NE, norepinephrine $\left(10^{-5} \mathrm{M}\right)$; PE, phenylephrine $\left(10^{-5} \mathrm{M}\right)$; I, isoprotere$\mathrm{nol}\left(10^{-5} \mathrm{M}\right)$; EGF $(20 \mathrm{ng} / \mathrm{ml})$. Experimental procedure is as described in Methods and in the legend of Fig. 2.

To our knowledge a direct mitogenic effect of catecholamines, in the absence of serum or other growth factors, has not been reported previously. In retrospect, however, it is perhaps not unexpected since a number of studies have indicated that some of the alpha adrenergic effects of catecholamines $\left(\alpha_{1}\right)$ are mediated by calcium (7) and since an increase in intracellular free calcium has been suggested to be a trigger for mitogenesis $(8,9)$. Our previous studies on centrosomal separation induced by EGF also suggested that this effect was triggered by increased intracellular calcium via calmodulin (2).

A central question raised by the present study is whether the mitogenic effect of epinephrine or norepinephrine occurs physiologically. The concentration of epinephrine required for maximal effect in our cells $\left(10^{-6} \mathrm{M}\right)$ is similar to that required for alpha receptor-mediated activation of glycogenolysis in perfused rat liver $(10)$ or isolated hepatocytes $(11,12)$ and for stimulation of potassium release from isolated parotid cells (13)

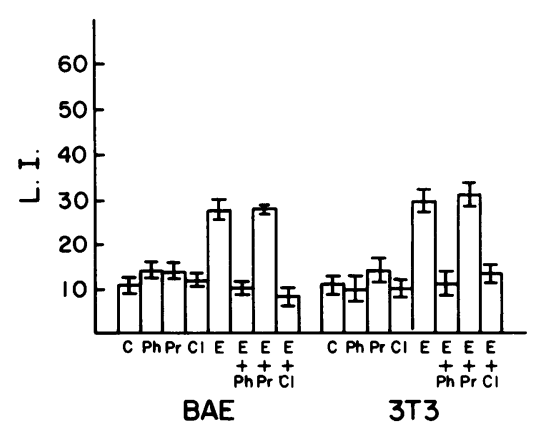

Figure 5. Effect of adrenergic blockers and clonidine on epinephrinestimulated DNA synthesis in BAE and 3T3 cells. All drugs were added $30 \mathrm{~h}$ after serum deprivation. Thymidine labeling and processing for autoradiography were done as described in Methods. C, Control (no addition); $\mathrm{Ph}$, phentolamine $\left(10^{-6} \mathrm{M}\right)$; $\mathrm{Pr}$, propranolol $\left(10^{-6}\right.$ $\mathrm{M})$; $\mathrm{Cl}$, clonidine $\left(10^{-5} \mathrm{M}\right)$; E, epinephrine $\left(10^{-5} \mathrm{M}\right)$.
Table II. Effect of Prazosin and Yohimbine on Epinephrine-induced DNA Synthesis

\begin{tabular}{lcr}
\hline & \multicolumn{2}{c}{ Labeling index (Mean \% \pm SE) } \\
\cline { 2 - 3 } Hormone/drug & Endothelial cells & \multicolumn{1}{c}{$3 \mathrm{~T} 3$ cells } \\
\hline None & $11.3 \pm 0.97$ & $9.0 \pm 1.35$ \\
EGF $(10 \mathrm{ng} / \mathrm{ml})$ & $36.3 \pm 2.73$ & $32.0 \pm 2.68$ \\
Epinephrine $\left(10^{-5} \mathrm{M}\right)$ & $32.2 \pm 1.43$ & $33.0 \pm 2.02$ \\
Prazosin $\left(10^{-5} \mathrm{M}\right)$ & $9.0 \pm 1.58$ & $10.7 \pm 1.87$ \\
Prazosin + epinephrine & $10.0 \pm 1.00$ & $13.0 \pm 1.68$ \\
Yohimbine $\left(10^{-5} \mathrm{M}\right)$ & $19.0 \pm 1.60$ & $26.7 \pm 1.58$ \\
Yohimbine + epinephrine & $28.2 \pm 2.22$ & $33.3 \pm 2.76$ \\
Prazosin + EGF & $32.6 \pm 2.12$ & $31.0 \pm 1.41$ \\
Yohimbine + EGF & $28.6 \pm 1.23$ & $29.5 \pm 1.45$ \\
\hline
\end{tabular}

All drugs were added $30 \mathrm{~h}$ after serum deprivation. Cells, labeled with $\left[{ }^{3} \mathrm{H}\right]$ thymidine $(1 \mu \mathrm{Ci} / \mathrm{ml})$ for $2 \mathrm{~h}$, were fixed and processed for autoradiography $18 \mathrm{~h}$ after drug addition.

but is somewhat higher than that required for enhanced hepatic glucose output in humans (14). The local concentration of norepinephrine released from nerve terminals is unknown but is presumably quite high. Perhaps during embryogenesis adrenergic amines modulate cell proliferation and organogenesis by localized effects mediated by the sympathetic nervous system. It also seems possible, as noted above, that there are other endogenous agents that may act through an $\alpha_{2}$-adrenergic receptor mechanism to inhibit cell growth in vivo; however, this is entirely speculative. Finally, we may wonder whether alpha adrenergic receptor stimulation is associated with the activation of a tyrosine protein kinase as is the case with a number of other growth

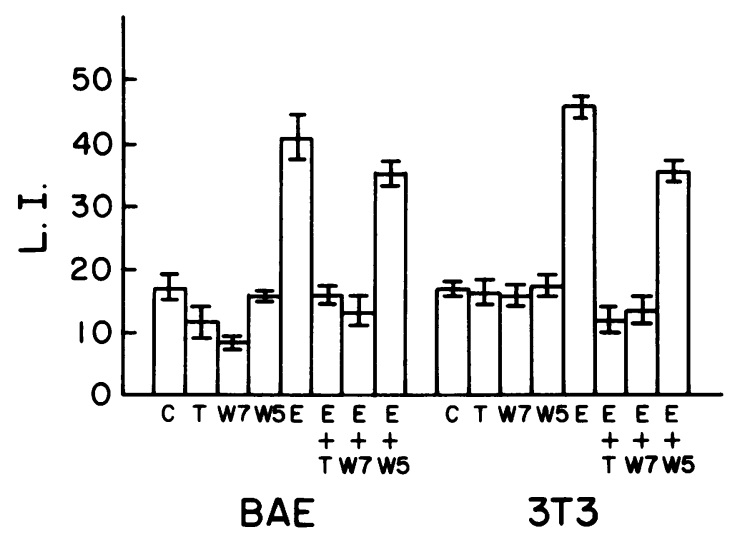

Figure 6. Effect of calmodulin inhibitors on epinephrine-stimulated DNA synthesis. All drugs were added $30 \mathrm{~h}$ after serum deprivation. Thymidine labeling and processing for autoradiography were done as described in Methods. C, Control (no addition); T, trifluoperazine $\left(10^{-5}\right.$ $\mathrm{M})$, E, epinephrine $\left(10^{-5} \mathrm{M}\right)$; W-5 and W-7 were used at $10^{-5} \mathrm{M}$. 
factors (15-19) as well as the proteins coded for by various cellular and viral oncogenes (20).

\section{Acknowledgments}

This work was supported by National Institutes of Health grant GM22497 and a Research Career Development Award (Dr. Sherline), and a grant from the University of Connecticut Research Foundation (Dr. Mascardo).

\section{References}

1. Sherline, P., and R. N. Mascardo. 1982. Epidermal growth factor induces rapid centrosomal separation in HeLa and 3T3 cells. $J$. Cell Biol. 93:507-512.

2. Sherline, P., and R. N. Mascardo. 1982. Epidermal growth factorinduced centrosomal separation. Mechanism and relationship to mitogenesis. J. Cell Biol. 95:316-322.

3. Mascardo, R. N., and P. Sherline. 1982. Somatostatin inhibits rapid centrosomal separation and cell proliferation induced by epidermal growth factor. Endocrinology. 111:1394-1396.

4. Baserga, R., and P. Malamud. 1969. In Autoradiography: Techniques and Applications. Harper \& Row Publishers, Inc., New York, 1971.

5. Hidaka, H., T. Yamaki, M. Naka, T. Tanaka, H. Hayashi, and R. Kobayashi. 1980. Calcium-regulated modulator protein interactingagents inhibit smooth muscle calcium-stimulated ATPase. Mol. Pharmacol. 17:66-72.

6. Nishikawa, M., and H. Hidaka. 1982. Role of calmodulin in platelet aggregation. J. Clin. Invest. 69:1348-1355.

7. Exton, J. H. 1982. Molecular mechanisms involved in $\alpha$-adrenergic responses. Trends Pharmacol. Sci. 3:111-115.

8. MacManus, J. P., A. L. Boynton, and J. F. Whitfield. 1978. Adv. Cyclic Nucleotide Res. 9:485-491.

9. Hidaka, H., Y. Sasaki, T. Tanaka, T. Endo, S. Ohno, T. Fujii, and T. Nagata. 1981. N-(6-aminohexyl)-5 chloro-1-naphthalenesulfonamide, a calmodulin antagonist, inhibits cell proliferation. Proc. Natl. Acad. Sci. USA. 78:4353-4357.

10. Sherline, P., A. Lynch, and W. H. Glinsmann. 1972. Clycic AMP and adrenergic receptor control of rat liver glycogen metabolism. Endocrinology. 91:680-690.

11. Tolbert, M., F. R. Butcher, and J. N. Fain. 1973. Lack of correlation between catecholamine effects on cyclic adenosine $3^{\prime}: 5^{\prime}$ monophosphate and gluconeogenesis in isolated rat liver cells. J. Biol. Chem. 248:5686-5692.

12. Hutson, N. J., F. T. Brumley, R. D. Assimacopoulos, S. C. Harper, and J. H. Exton. 1976. Studies on the adrenergic activation of hepatic glucose output. J. Biol. Chem. 251:5200-5208.

13. Strittmatter, W. J., J. N. Davis, and R. J. Lefkowitz. 1977. $\alpha$ adrenergic receptors in rat parotid cells. J. Biol. Chem. 252:5478-5482.

14. Rizza, R. A., M. W. Haymond, J. M. Miles, C. A. Verdonk, P. E. Cryer, and J. E. Gerich. 1980. Effect of $\alpha$-adrenergic stimulation and its blockade on glucose turnover in man. Am. J. Physiol. 238:E467472.

15. Carpenter, G., L. King, Jr., and S. Cohen. 1979. Rapid enhancement of protein phosphorylation in A-431 cell membrane preparations by epidermal growth factor. J. Biol. Chem. 254:4884-4891.

16. Cohen, S., G. Carpenter, and L. King. 1980. Epidermal growth factor-receptor protein kinase interactions. J. Biol. Chem. 255:48344842.

17. Hunter, T., and J. A. Cooper. 1981. Epidermal growth factor induces rapid tyrosine phosphorylation of proteins in A431 human tumor cells. Cell. 24:741-752.

18. Ek, B., B. Westermark, A. Wasteson, and C. H. Heldin. 1982. Stimulation of tyrosine specific phosphorylation by platelet derived growth factor. Nature (Lond.). 295:419-420.

19. Kasuga, M., Y. Zick, D. Blithe, M. Crettaz, and C. R. Kahn. 1982. Insulin stimulates tyrosine phosphorylation of the insulin receptor in a cell-free system. Nature (Lond.). 298:667-669.

20. Hunter, T. 1982. Phosphotyrosine-a new protein modification. Trends Biochem. Sci. 1:246-249. 